CZU 323.1(478)

DOI https://doi.org/10.52388/1812-2566.2021.3(94).09

\title{
PECULIARITIES OF INTERETHNIC PERCEPTION OF THE GAGAUZ AND BULGARIANS IN THE REPUBLIC OF MOLDOVA
}

\author{
Larisa HOROZOVA \\ Doctor of Psychological Sciences, \\ Comrat State University, Comrat, Republic of Moldova \\ e-mail: larisahorozova@yandex.ru \\ https://orcid.org/0000-0002-6567-0334 \\ Sergey HOROZOV \\ Doctor of Sociological Sciences, \\ Comrat State University, Comrat, Republic of Moldova \\ e-mail: horozovserghei11@gmail.com \\ https://orcid.org/0000-0002-0599-4767
}

Moldova is a multi-ethnic state. One third of the country's population is national minorities, including the Gagauz and Bulgarians. There is material evidence in history that negative stereotypes and conflicts existed between two ethnic groups in the region in the early 19th century. But over time, relations between the Gagauz and Bulgarians lost their former acuteness. The article substantiates the need to study ethnic heterostereotypes of the Gagauz and Bulgarians as a brandtheir ethnic identity. The results of the conducted empirical study of ethnic heterostereotypes of the Bulgarian and Gagauz youth prove that in the sphere of intergroup perception, these ethnic groups have a problem-distance from each other. There is a certain tension in the relationship between the Gagauz and Bulgarians, which manifests itself in a hidden, smoldering form. It is expressed in social competition, achieved by ethnocentric evaluative comparison of one's own and another's group in favor of one's own. But, nevertheless, they also have a powerful resource-a positive ethnic identity, which includes not only a positive self-identification, but also a positive image. The authors conclude that it is necessary to strengthen the positive ethnic identity of the Gagauz and Bulgarian youth. Increasing intercultural communication and competence is the main way to bring these two closely adjacent ethnic groups closer together.

Keywords: ethnic identity, ethnic stereotype, ethnic heterostereotype, Gagauz, Bulgarians, Republic of Moldova.

\section{PARTICULARITĂȚILE PERCEPȚIEI INTERETNICE A GĂGĂUZILOR ȘI BULGARILOR ÎN REPUBLICA MOLDOVA}

Moldova este un stat polietnic. O treime din populația țării o reprezintă minoritățile naționale, inclusiv găgăuzi și bulgari. Există dovezi materiale în istorie că stereotipuri și conflicte negative existau între două grupuri etnice din regiune deja la începutul secolului al XIX-lea. Dar, în timp, relațiile dintre găgăuzi și bulgari și-au pierdut fostul caracter acut. Autorii susțin necesitatea studierii heterostereotipurilor etnice ale găgăuzilor și bulgarilor ca marker al identității lor etnice. Aceștia concluzionează că este necesar să se consolideze identitatea etnică pozitivă a tinerilor găgăuzi și bulgari. Creșterea comunicării și competenței interculturale este principala modalitate de a apropia aceste două grupuri etnice apropiate identitatea lor etnică. Rezultatele studiului empiric efectuat al heterostereotipurilor 
etnice ale tinerilor bulgari și găgăuzi demonstrează că în sfera percepției intergrupale, aceste grupuri etnice au o problemă - distanța între ele. Există o anumită tensiune în relația dintre găgăuzi și bulgari, care se manifestă într-o formă ascunsă, mocnită. Se exprimă în competiție socială, realizată prin comparație etnocentrică evaluativă a propriului și o imagine pozitivă.

Cuvinte-cheie: identitate etnică, identitate stereotip etnic pozitivă, heterostereotip etnic, găgăuzi, bulgari, Republica Moldova.

\section{PARTICULARITÉS DE LA PERCEPTION INTERETHNIQUE DES GAGAOUZES ET BULGARES DANS LA RÉPUBLIQUE DE MOLDOVA}

Moldova est un état multiethnique. Un tiers de la population du pays est constitué de minorités nationales, dont les Gagaouzes et les Bulgares. Il existe des preuves matérielles dans l'histoire que des stéréotypes négatifs et des conflits existaient entre deux groupes ethniques dans la région au début du XIXe siècle. Mais au fil du temps, les relations entre les Gagaouzes et les Bulgares ont perdu leur ancienne acuité. L'article justifie la nécessité d'étudier les hétérostéréotypes ethniques des Gagaouzes et des Bulgares comme marqueur de leur identité ethnique. Les résultats de l'étude empirique menée sur les hétérostéréotypes ethniques des jeunes bulgares et gagaouzes prouvent que dans la sphère de la perception intergroupe, ces groupes ethniques ont un problème - la distance les uns des autres. Il y a une certaine tension dans la relation entre les Gagaouzes et les Bulgares, qui se manifeste sous une forme cachée et fumante. Elle s'exprime dans la compétition sociale, obtenue par une comparaison évaluative ethnocentrique de son propre groupe et de celui d'un autre en faveur du sien. Mais, néanmoins, ils ont aussi une ressource puissante - une identité ethnique positive, qui comprend non seulement une auto-identification positive, mais aussi une image positive de "l'Autre». La conclusion est faite sur la nécessité de renforcer l'identité ethnique positive de la jeunesse gagaouze et bulgare. L'augmentation de la communication et des compétences interculturelles est le principal moyen de rapprocher ces deux groupes ethniques étroitement adjacents.

Mots-clés: identité éthnique, stéréotypes ethnique, hétérostéréotypes ethnique, Gagaouzes, Bulgares, République Moldova.

\section{ОСОБЕННОСТИ МЕЖЭТНИЧЕСКОГО ВОСПРИЯТИЯ ГАГАУЗОВ И БОЛГАР В РЕСПУБЛИКЕ МОЛДОВА}

Молдова - полиэтническое государство. Третья часть населения страны является национальными меньшинствами, среди которых -гагаузы и болгары. В истории имеются материальные свидетельства того, что негативные стереотипы и конфликты существовали между двумя этническими группами в регионе в начале 19 века. Но со временем отношения между гагаузами и болгарами потеряли былую остроту. В статье обосновьвается необходимость изучения этнических гетеростереотипов гагаузов и болгар как маркера их этнической идентичности. Результаты проведённого эмпирического исследования этнических гетеростереотипов болгарской и гагаузской молодежи доказывают, что в сфере межгруппового восприятия у данных этнических групп есть проблема - дистаниированность друг от друга. Во взаимоотношениях гагаузов и болгар существует определённая напряжённость, проявляющаяся в скрытой, тлеющей форме. Она выражена в сочииальной конкуренции, достигаемой этноцентристским оценочным сравнением своей и чужой группы в пользу собственной. Но, тем не менее, у них имеется и мощный ресурс - позитивная этническая идентичность, включающая не только позитивную самоидентификацию, но и позитивный образ «Другого». Делается вывод о необходимости усиления позитивной этнической идентичности гагаузской и болгарской молодёжи. Повышение межкультурной коммуникации и компетентности - основной путь к сближению этих двух близко соседствующих этнических групп

Ключевые слова: этническая идентичность, этнический стереотип, этнический гетеростереотип, гагаузы, болгары, Республика Молдова. 
Nowadays, most of the countries can be claimed as polyethnic or multicultural. "Multicultural societies are considered to be those countries which include many (more than two) ethnic groups with a significant population number, regardless of how long they have been living in a given territory, whether they are "indigenous" or migrants, "titular" or "non-titular" [7, p.14].

Moldova is a multiethnic state, its territory is a unique intersection of the slavonic, roman and turk cultures. One third of the population (\% 35.5) is the national minorities, that are made up of Gagauz, and Bulgarians, as well.

According to the latest census data, Gagauz make up $4.5 \%$ of the republic population. In terms of population, the Gagauz occupy the fourth place after the Moldovans (the titular ethnic group), Ukranians and Russians. The Bulgarian population in the country is $1.8 \%$ of the total population of the country (without Transnistria). In ATU Gagauz Yeri, the number of Gagauz is $83.8 \%$ of the total population of the region, Bulgarians - $4.9 \%$ [13].

Bulgarians and Gagauz of Moldova are representatives of ethnic groups whose ancestors moved to the territory of modern Moldova in the 18th century from the territory of modern Bulgaria. The ancestors of today's Bulgarians live in Bulgaria. The Gagauz people do not have a "historical" homeland, they had been formed as an ethnic group on the territory of Moldova. Both ethnic groups are close in their cultural and daily traditions, historical destinies; both belong to the same religious branch (Orthodox Christians) and both live in the historical region of Budjak in stripes or mixed. Therefore, these ethnic groups should be considered together in the context of their ethnocultural development.

\section{The relevance of research}

The study of the phenomenon of ethnic identity of ethnic groups of the Gagauz and Bulgarians in the psychological aspect seems to us relevant, since ethnic identity has a great predictive potential. It has both stability, the ability to be passed on from generation to generation, and variability, the ability to "hide" in a latent state and become more active in a situation of interethnic interaction or a common external threat.

In the context of the study of the ethnic identity of the Gagauz and Bulgarians, it is advisable to study their ethnic stereotypes. A stereotype is an image created by the historical practice of interethnic relations and almost does not lend itself to arbitrary change, has powerful psychoenergetics. It allows the group to identify itself in the vortex of history [10].

When studying the ethnic identity of the young people of the Gagauz and Bulgarians, we proceeded from the fact that the ethnic stereotype is a basic, emotionally evaluative component in the structure of ethnic identity. Preferences and assessments towards your own and the other groups are manifested are manifested through this ethnic identity.

To understand the peculiarities of the content of ethnic stereotypes of Bulgarians and Gagauz, a study conducted by the Moldovan psychologist I.I. Kaunenko is of interest. on the problem of the perception of time and sociocultural changes through collective memory by various ethnic groups (including Bulgarians and Gagauz [4, p. 49-58].

To study this problem, she included the question in the survey: "What events should your children remember?" This question was borrowed from the research of A.V. Kuznetsova, who studied the collective memory of significant events in various social groups [5, p. 106]. It makes it possible to track trends in the construction and transmission of memories, as well as to understand how representatives of ethnic groups, on the one hand, reflect on sociocultural changes in society, and on the other hand, what is ready to transmit to the younger ge- 
neration, since "one of the powerful mechanisms for transmitting the ideas of the collective memory into the future is a directly realized desire to create the desired image of the past in the younger generation. "filled with happy moments, travel, vacation trips"; "To remember that they had a good childhood, when everyone loves them, presents them with purchases, and pays attention." The next most important category is "Traditions, customs, history of the people $(21 \%)$ - "traditions and customs of the people so as not to lose the history of the people"; "Must remember the history of their people"; "To know and honor traditions". It can be concluded that among a group of Bulgarians, the main semantic categories for intergenerational transmission are the subcategories "Transfer of traditions, family events". Historical events occupy an insignificant place (6\%) (event in Odessa on May 2; World War II).

Gagauz prioritize "Family" (62\%) as the most significant category that they would like to broadcast to children is: "birthdays of each family member", "to meet on these days", "birthdays of relatives", "own childhood", "Time spent with family." The subcategories "Family Holidays" and "Relationships" were equally divided (50\% each). The second most important category is "Historical events" $(16 \%)$ - "proclamation of the Gagauz republic", the independence of the Republic of Moldova". The third category is the category "Traditions, customs, history of our people" (13\%) - "to honor the customs and traditions of our people, wherever we are". So, for the Gagauz group, the semantic categories for intergenerational transmission are "Family", "Historical events", "Traditions, customs, history of their people".

So, the study of the perception of time and socio-cultural changes through collective memory among ethnic groups of Bulgarians, Gagauz, revealed that one of the basic categories (through which sociocultural changes in society are perceived) is the category "Family". The most frequent events they highlight are those related to family celebrations, rituals, and family relationships. Difficulties in categorizing and reflecting socio-cultural changes in society in the perception of the world among representatives of ethnic groups activate the categories of the "close circle" - family, kindred intergenerational solidarity.

The features revealed by the researcher of the perception of the youth of the Gagauz and Bulgarians of time and socio-cultural changes through collective memory leave their mark on the formation of their ethnic stereotypes.

It should be noted that an ethnic stereotype can be autostereotype by its nature (i.e., describing one's own group) or a heterostereotype (i.e., describing another ethnic group), reflecting, albeit in a distorted or transformed form, objective reality: the properties of two interacting groups and the relationship between them.

The aim of our research was to study the ethnic heterostereotypes of the Gagauz and Bulgarians.

The sample consisted of 329 people. These are young men and women 18-25 years old, students of the Comrat State University (stationary, correspondence departments, as well as students of advanced training courses at the university). Study region: ATU Gagauz Yeri of the Republic of Moldova.

Ethnic stereotype was investigated by us using the basic methodology - "Diagnostic test of attitudes" (DTO) by G.U. Soldatova [9]. It allowed to measure the parameters of an ethnic stereotype, namely: the degree of agreement - ambivalence (A); intensity, strength of the stereotyped effect - severity (S); general positive or negative perception of the object of stereotyping - directionality (D); content is a set of characteristics attributed to an ethnic group. 
We first identified the average values of the coefficients of ambivalence (A), severity (S), direction (D) of mutual heterostereotypes of the Gagauz and Bulgarians (hereinafter - ASD).

Then the heterostereotypes of the Gagauz / Bulgarians were compared. The comparison was carried out on the basis of comparing their coefficients of ambivalence (A), severity (S), direction (D). To assess the reliability of the data obtained, the Dunn test for multiple comparisons with the Bonferroni correction was used.

Further, the content of ethnic heterostereotypes was analyzed. For this, for each ethnic group (Gagauz and Bulgarians), the average scores were calculated for all 24 qualities of the method. The qualities that received the highest scores (above 3 ) were considered stereotyped, the most typical for this ethnic group.

Let us present the results of the study of ethnic heterostereotypes of student youth of the Gagauz and Bulgarians.

\section{Main results of the rescarch}

Analysis of the data of the average values of the coefficients of ambivalence (A), direction (D), severity (S) of mutual ethnic heterostereotypes revealed that the Gagauz and Bulgarian youth have a positive ethnic identity, since all indicators are with $\mathrm{a}+\operatorname{sign}($ table 1 ). It is worth noting here that earlier we have revealed a positive self-identification and a positive image of other ethnic groups (Moldovans, Russians [13]) among the youth of the Gagauz and Bulgarians. The youth of Bulgarians, as well as the youth of the Gagauz, have low indicators of orientation (D) of mutual heterostereotypes. The weakly expressed strength of the stereotypical effect (S) in both ethnic groups indicates a certain distance between the youth of the Gagauz and Bulgarians relative to each other.
Table 1. Average values of the coefficients of ambivalence (A), severity (S), orientation (D) of ethnic heterostereotypes - youth of Gagauz and

\section{Bulgarians}

\begin{tabular}{|l|c|c|c|}
\hline \multirow{2}{*}{ Assessment type } & \multicolumn{3}{|c|}{$\begin{array}{c}\text { Heterostereotype } \\
\text { parameters }\end{array}$} \\
\cline { 2 - 4 } & A & S & D \\
\hline $\begin{array}{l}\text { Heterostereotype of } \\
\text { Gagauz }\end{array}$ & 0,67 & 0,07 & 0,07 \\
\hline $\begin{array}{l}\text { Heterostereotype of } \\
\text { Bulgarians }\end{array}$ & 0,69 & 0,08 & 0,07 \\
\hline
\end{tabular}

Source: The author's calculations based on research data: "Ethnic identity of student youth in the conditions of labor migration of the population in ATU Gagauz Yeri. 2019 [12].

We can suppose that long-term living nearby, possibly, leads to the fact that the mechanism of psychological defense is triggered, when a high blurring of the image of the "others" is manifested through a decrease in the severity of the stereotype. There is material evidence in history that negative stereotypes and conflicts existed between two ethnic groups in the region in the early 19th century. But over time, relations between the Gagauz and Bulgarians lost their former acuteness [11].

In order to identify the differences between which objects of assessing the ethnic stereotype of the Gagauz and Bulgarians are statistically significant, we used the Dunn test for multiple comparisons with the Bonferroni correction.

Among the students Gagauz, statistically significant differences were revealed when comparing the auto-stereotype of the Gagauz with the heterostereotype of the Bulgarians $(Z=0.926, p=0.001)$, as well as when comparing the image of the "I" of the Gagauz with the heterostereotype of the Bulgarians $(\mathrm{Z}=1.570, \mathrm{p}=0.001)$, which indicates differentiati- 
on (one's own - another) of the Gagauz youth from the Bulgarian ethnic group at the group and personal levels. The heterostereotype is characterized by a high level of ambivalence and a low strength of the stereotyped effect.

Among the students Bulgarians, statistically significant differences were revealed when comparing the auto-stereotype of Bulgarians with the heterostereotype of the Gagauz $(\mathrm{Z}=1.375, \mathrm{p}=0.001)$, as well as when comparing the image of the "I" of Bulgarians with the heterostereotype of the Gagauz ( $\mathrm{Z}$ $=2.315, \mathrm{p}=0.001$ ), which also can be considered as the evidence of the differentiation (one's own - another) of Bulgarians from the Gagauz ethnic group at the group and personal levels. The heterostereotype of the Gagauz people is characterized by a high level of ambivalence, low emotional saturation.

We were surprised by the empirical data obtained among the youth of Bulgarians in the image of the Gagauz and among the youth of the Gagauz in the image of the Bulgarians, described above, because these groups have been living side by side for a long time. It seems that two moments can be at work here: the first is the difference between the Turkic and Slavic cultures, this is one "watershed", the second is a long-term residence nearby, which sometimes generates a certain distance for the self-preservation of the group. The phenomenon identified by us requires special research in the field of interethnic relations between Bulgarians and Gagauz, social perception of each other.

Ukrainian historian A.V. Shabashov explained such a distancing in relations between the Gagauz and the Bulgarians by the fact that the Gagauz, being ethnoculturally close to the Bulgarians (as a result of centuries of living nearby), can exist as an independent ethnic group only with a certain distance from them, focusing not on common features, but differences with the Bulgarians. Moreover, these differences can be exaggerated and even lead to dislike.
In his opinion, this is one of the main functions of ethnicity at the psychological level: to differentiate the representatives of "one's own" group, of "one's own" ethnic group from representatives of "foreign" groups. Additionally, the closer ethnic groups, the researcher believed, the more motivation for such a confrontation in order to preserve their own ethnicity. And vice versa - the more another ethnos is removed by culture and other characteristics from its own, the more it is not similar, the more the attitude towards it is even and neutral [11].

One of the options for explaining such a distance between the Gagauz and Bulgarians is also found in the articles of historian N.V. Anikin, who studied the problems of ethnic identification of the Gagauz. This is how he explains the distance between Bulgarians and Gagauz at the present stage: "During the turbulent political events of 1989-1991, which led to the emergence of national autonomy within the Republic of Moldova in 1994, the Bulgarians and Gagauz of the Moldovan part of Budjak were again divided, into this times the administrative boundaries of ATU Gagauzia and Taraclia region. The political elites of the Bulgarians and Gagauz were unable to moderate their own ambitions and transform the historical unity of the two peoples into political forms. And the administrative boundaries were drawn without taking into account ethnic, cultural and economic aspects, artificially dividing the Bulgarian-Gagauz population compactly living in the region by state and administrative boundaries. Hence, a certain distance between the Bulgarians from the ethnic groups of the Gagauz and the preservation of mutual clai$\mathrm{ms}$ and frictions between the Bulgarian and Gagauz political elites, which complicates the long-standing ties between the two historically close peoples" [1, p. 21].

Researchers when living nearby for a long time, as a result of cultural borrowing, ethnic groups can sometimes have a certain "blur" of each other's 
images. In addition, these groups belong to different cultures: Bulgarians - to Slavic [2], Gagauz - to Turkic $[1 ; 8]$. Therefore, another assumption is possible: these features of heterostereotypes relative to each other can be caused to a certain extent by the psychological defense of the image of their ethnic group.

Further, in order to make clear the obtained results, we analyzed the content of mutual ethnic heterostereotypes of the young Gagauz and Bulgarians.

When analyzing the content of ethnic heterostereotypes, we proceeded from the assumption that stereotypes are determined by the specifics of the stereotyped group, the duration and depth of historical contacts with other ethnic groups. The most stereotyped qualities were those that were assessed at the level of 3 points and higher (table 2.).

Table 2. Mutual ethnic stereotypes of Gagauz and Bulgarians students

\begin{tabular}{|c|c|c|c|}
\hline \multicolumn{2}{|c|}{ Gagauz about Bulgarians } & \multicolumn{2}{|c|}{ Bulgarians about Gagauz } \\
\hline $\begin{array}{l}\text { The most } \\
\text { frequent } \\
\text { qualities }\end{array}$ & Average & $\begin{array}{l}\text { The most } \\
\text { frequent } \\
\text { qualities }\end{array}$ & Average \\
\hline talkative & 3,17 & talkative & 3,36 \\
\hline thrifty & 3,17 & temperamental & 3,33 \\
\hline greedy & 3,03 & persistent & 3,22 \\
\hline stubborn & 3,01 & proud & 3,17 \\
\hline temperamental & 2,95 & active & 3,13 \\
\hline active & 2,91 & hot-tempered & 3,13 \\
\hline
\end{tabular}

Source: The author's calculations based on research data: "Ethnic identity of student youth in the conditions of labor migration of the population in ATU Gagauz Yeri. 2019 [12].

As you can see, among the youth of Bulgarians and Gagauz, the "end-to-end" quality of all assess- ments is - sociability as a manifestation of the communicative sphere.

Bulgarians include irascibility in the image of the Gagauz, which is well-founded. Our survey of the Gagauz youth regarding the typical features of the representatives of their group also revealed that the Gagauz people sometimes characterized themselves as hot-tempered and stubborn. So the image of the Gagauz people among the youth of the Bulgarians has grounds for adequacy.

As, however, the youth of the Gagauz people in the image of the Bulgarians are noted for frugality and greed. The researcher of the Gagauz ethnos A.V. Shabashov noted that the Gagauz people had ideas about the greed and avarice of the Bulgarians in the past [11]. Back in the early 19th century, V.A. Moshkov, characterizing the Bulgarians, noted that the Gagauz people say that they are a greedy and stingy people. He wrote that the Bulgarian or toucan is a common noun for the Gagauz. The phrase "ali Bulgar (toucan)" literally translates: "exactly like a Bulgarian, with the meaning "greedy, like a Bulgarian", which means: to call a person a Bulgarian and accuse him of stinginess [8]. I. Kaunenko's research on the ethnic identity of the youth of Bulgarians also noted a high stereotyping in the auto-stereotype of the characteristics of economy [3].

The thriftiness of the Bulgarians (and for the Gagauz people - greed) was reflected in the works of oral folk art of the Bulgarians: proverbs, sayings, became the subject of anecdotes. So, far beyond the borders of Bulgaria, the humor of the inhabitants of one of the cities of Bulgaria - Gabrovo is known. Excessive frugality and greed of Bulgarians are the main themes of their anecdotes.

In classical Bulgarian literature, the name of the protagonist of the eponymous work of the famous Bulgarian classic Aleko Konstantinov "Bai Gagno" has long become a household name in Bulgaria: he is spontaneous in his unrestrained greed. It is worth 
noting, though, that in critical judgments about Bai Gagno, two main lines took shape. According to one, “... Bai Gagno is a national or racial, biological or cultural, but, in any case, not a socio-historical or class type with a set of the most unsympathetic features. According to another line, researchers deny the national character of the image and believe that it reflects the qualities that are not specific to Bulgarians, and the general ones are inherent in any uncultured people" [6, p. 91].

\section{Conclusions}

So, an empirical study of the ethnic heterostereotypes of the youth of the Gagauz and Bulgarians at the present stage, when the Moldovan society is undergoing profound transformations, revealed that:

- The youth of the Gagauz and Bulgarians have mutual ethnic heterostereotypes - positive. Positive self-identification and a positive image of other ethno-contact groups (Moldovans, Russians) can be the basis for the successful integration of the youth of the Gagauz and Bulgarians into the ethnocultural space of the country, as well as for the formation of civic identity, since tolerance in interethnic relations is formed on the basis of positive ethnic identity.

- Mutual heterostereotypes of Bulgarians / Gagauz students are characterized by a low level of stereotyping. They are diffuse, ambivalent, characterized by a low level of severity and focus.

- We assume that the distance of ethnic groups from each other, on the one hand, is due to the civilizational border "Slavic - Turkic", on the other hand, psychological protection during long-term territorial cohabitation and rapid ethno-cultural transformations in society. Defense mechanisms are activated, and then some ethnic markers, including qualities, become a protective cordon. But for a more substantiated answer to this phenomenon, special research is needed.
- The most stereotyped qualities of mutual images of Gagauz and Bulgarians are sociability, activity, temperament. But there are also peculiarities of each image of an ethnic group: for the Gagauz it is pride, perseverance, hot temper, and for Bulgarians it is economy, greed, stubbornness.

Further monitoring of heterostereotypes of various ethno-contact groups on the territory of the country in conditions of cohabitation and rapid ethnocultural transformations in society is very important, since heterostereotype is an image created by the historical practice of interethnic relations, it almost does not lend itself to arbitrary change, has great predictive potential.

Thus, there is a certain tension in the relationship between the Gagauz and Bulgarians, which manifests itself in a hidden, smoldering form. It is expressed in social competition, achieved by ethnocentric evaluative comparison of one's own and another's group in favor of one's own.

Enhancing intercultural communication and competence is the main path to the rapprochement of these two closely adjacent ethnic groups, where the main principles should be:

1. Development of understanding of another culture through a better awareness of their cultural identity, the characteristics of their culture.

2. Development of knowledge and a positive interest in everything new and unfamiliar that can be found in another culture - in traditional norms, customs, and behavioral characteristics that differ from one's own.

3. Development of the qualities inherent in a multicultural personality, the formation of openness and readiness to accept intercultural differences, the development of tolerance towards representatives of different cultures. 


\section{Bibliography}

1. АНИКИН, Н. Проблемы этнической идентичности гагаузов Молдавии. Авт. дисс. канд. ист. наук. M. 2009. $146 \mathrm{c}$.

1. ЗАБУНОВ, И.Д. Болгары Молдовы: проблемы истории и культуры. В: Национальные образы мира: единство-разнообразие-справедливость. К: Штиинца, 2003. c.165-173.

2. КАУНЕНКО, И.И. Проблемы этнической идентичности или Свой Путь. В: Журнал исследований восточно-европейского Пограничья «Перекрестки», 2007, нм. 3-4, Вильнюс. с. 123-151

3. КАУНЕНКО, И. Особенности восприятия времени и социокультурных изменений через коллективную (семейную) память у этнических групп Республики Молдова. В: Сборник докладов и сообщений республиканской научно-практической конференции “Традиционная семья и вызовы современности”. Комрат: Научно-исследовательский центр Гагаузии им. М. В. Маруневич, 2020. С.49-58 ISBN 978-99753427-4-2.

4. КУЗНЕЦОВА, А.В. Коллективная память о значимых событиях и фигурах российской истории в различных социальных группах. Диссерт. канд. псих. наук. M, 2013, с.106
5. Литература за 10 клас на единото средне политехническо училище. София: Народна просвета, 1999. $91 \mathrm{c}$.

6. ЛЕБЕДЕВА, Н.М., ЛУНЕВА, О.В., СТЕФАНЕНКО, Т.Г. Тренинг этнической толерантности для школьников. М.: Издательский Дом «Ключ, 2004. $321 \mathrm{c}$.

7. МОШКОВ, В.А. Гагаузы Бендерского уезда. В: Этнографическое обозрение. М: Просвещение, 2004. $132 \mathrm{c}$.

8. СОЛДАТОВА, Г.У. Психология межэтнической напряженности. М. Смысл, 1998

9. СТЕФАНЕНКО, Т.Г. ЭТнопсихология. - М. Институт психологии РАН. Академический Проект, Екатеринбург: Деловая книга, 2000,c. 210

10. ШАБАШОВ, А.В. Болгары и гагаузы Украины: проблемы и перспективы этнокультурного развития. B: Инновационное развитие Республики Молдова: национальныезадачи и мировые тенденции. Comrat: A\&V Poligraf, 2013. c. 438-439

11. ХОРОЗОВА, Л.Ф. Этническая идентичность студенческой молодёжи в условиях трудовой миграции населения в Ато Гагауз Ери/Дисс...докт. психол. наук.-К.,2019.

12.https://statistica.gov.md/pageview. php? $=$ ru\&idc $=479 \&$ (Посещение: 15.02 .2021$)$ 